\title{
Avrupa Birliği’ni Sarsan Deprem: İnsani Güvenlik Bağlamında Covid-19
}

\author{
Earthquake Shaking the European Union: Covid-19 in Human Security Context
}

\author{
Fulya Köksoy*
}

\begin{abstract}
States have remained pretty fragile because of the lack of proper strategy and capacity in the struggle with Covid-19 that first emerged in Wuhan City of China in December 2019 and spread into the whole world at a great pace; for the latest data, more than 500 thousand people lost their lives and there are more than 10 millions of cases all around the world. The casualty arising from this pandemic that catches the world off guard is pretty large-scale. The pandemic that has spread to the globe by the effect of globalization created an shock effect for the European Union (EU) as well; the union as a whole and also the member states could not attain success in the struggle with this pandemic. There has started an inversion from traditional security approaches that prioritize state security only within the frame of size-changing threats after the cold war to the new security approaches which focus the security of factors like individual, environment, economy, and technology in addition to the security of the state. Thus, it has been understood how important human security is at the axis of new security approaches whose focal point is the human. In this manner, this paper draws a general frame about the effects of Covid-19 on the human security in the context of EU; we also appropriate the related analysis as part of Germany, France, Italy, and Spain within the frame of being the most affected states by the crisis; having the biggest armament, largest economy and highest number of chairs in the Parliament of Europe; providing the highest contribution to EU's budget. The chief goal of such research is to contribute to Turkish literature by analyzing this new pandemic within the frame of EU and human security. The status of member states has been problematized in the struggle with related pandemic pursuant to the observations that traditional security approaches without human security orientation are not effective against the pandemic and also the states who have the biggest military and economic capacities remain fragile against the pandemic; this paper also concretizes the current status at the axis of the numeric data.
\end{abstract}

Structured Abstract: According to experiences, traditional security approaches that approach from a narrow perspective to security by being state-oriented and protecting states against other states and terror problem have not provided any solutions toward the virus within the context of this virus which is known as Covid-19 and also which first emerged in the Wuhan City of China and engraved in the whole world by results. This situation gives room to the human security concept as part of the new security approaches which put the human in focus. In other words, this pandemic once again shows how important human security is.

\footnotetext{
* Dr. Öğr. Üyesi, Batman Üniversitesi, İktisadi ve İdari Bilimler Fakültesi, Uluslararası İlişkiler Bölümü Asst. Prof. Dr., Batman University, Faculty of Economics and Administrative Sciences, Department of International Relations

ORCID 0000-0002-6915-5620

fulyakoksoy@gmail.com

Cite as/ Atıf: Köksoy, F. (2020). Avrupa Birliği'ni sarsan deprem: İnsani güvenlik bağlamında Covid-19. Turkish

Studies, 15(6), 663-682. https://dx.doi.org/10.7827/TurkishStudies.44913

Received/Geliş: 07 July/Temmuz 2020

Accepted/Kabul: 15 October/Ekim 2020

Copyright $(\mathrm{C}$ MDE, Turkey
} 
Covid-19 in which security agenda that grounds on humanitarian values in the context of providing fundamental rights, needs, living conditions, and protecting individuals from all the threats has become a serious threat for human security centered on the priority of the individual and also Covid-19 for the last eight months. This pandemic is a global crisis as well as it has created the earthquake effect for both the European Union (EU) and the member states. This related epidemic that catches all the states and all the members of EU flatfooted has created an extra problem to EU's struggle with the long-termed economic crisis, rising populism, anti-immigrant mentality, rising nationalism, ethnocentrism and also the troubles arising from Brexit. The concrete reality, except the ongoing discussions related to the future of the EU in the context of the related pandemic, is the serious human security problem on the platform of both EU and all the member states and also specific to the most powerful states of EU such as Germany, France, Italy, and Spain.

It is concluded that related pandemic that has caused a human security crisis on both the platform of EU and Germany, France, Italy with Spain threatens the health and economic security of related states and becomes a serious threat for human security in the end. With reference to the high rates of human casualties in the context of Germany, France, and Italy arising from the pandemic, it is seen in the analysis that was conducted by utilizing the population of related states about Eurostat's data on the number of hospital beds and doctors per 100 thousand people that other three important member states including Germany have capacity problems in health care; this reflects the problematic structure regarding health safety. On the other hand, due to the pandemic, there are factors such as shrinkage for markets and demands, precautions taken at the borders, interruption of production, the closing of workplaces, curfews, and travel bans under the deterioration of the economic security balance. Recessions in the economy of states, slowing down economic activities, and increasing the general price levels because of the pandemic are the remarkable issues that directly affect the individuals. On the other hand, Germany displays a successful struggle in the context of developed awareness level of public and quick action mechanism in emergencies rather than a developed health capacity that has been continuously emphasized while France, Italy and Spain could not reach a high success level in the direction of falling short of health services mechanism; having higher old age population ratio compared to young population; being delayed to take precautions toward struggling with pandemic late.

On the other hand, the European Union that is both supranational and intergovernmental could not provide solidarity by making a common union plan in the struggle with the pandemic. It has been experienced once more that the issue of creating a European society within the scope of social solidarity and unity could not be made actual via integration. Precautions that have been taken as part of the struggle with pandemic impede the functionality of the EU mechanism that is established on the free movement of goods, services, capital, and people. Moreover, we also observe that EU's human security discourse that has their origins in 'European Security Strategy' document in 2003; that is crowned by 'Barcelona Convention' published in 2004; 'Madrid Convention' published in 2007; 'European Global Strategy' published in 2016 remains a theory. On the other hand, it is also seen that cooperation within the EU has remained at the international level; precautions have remained within the states themselves. Measures at the national platform remain incapable of removing this problem that affects the whole world; this also causes international cooperation to become clear at this point.

States, in general, focused on their own security until this new global threat. However, the pandemic has caused mortality to highly increase and affected the economic, social, and political textures of states; these issues establish the elements of human security. Moreover, for conclusions, having a national security approach that is primarily based on military elements is not a solution for such threats. The issue that states need to develop individual-oriented behavior patterns; strengthen health services capacities and allocate sufficient cash resources comes into prominence. In fact, epidemics necessitate a global challenge and collective struggle at the same time. Briefly, this issue that is also experienced in the context of the EU reveals the need for a human security approach that is based on more comprehensive, holistic, common will and cooperation throughout the whole world and specific to the Union.

Keywords: European Union, Human Security, Coronavirus (Covid-19), Germany, France, Italy, Spain

Öz: İlk olarak 2019 yılı Aralık ayında Çin’in Wuhan kentinde görülen ve büyük hızla tüm dünyaya yayılan Covid-19 salgını ile mücadelede uygun strateji ve kapasite eksikliği nedeniyle hükûmetler oldukça kırılgan kalmış, son verilere göre dünya çapında 10 milyonu aşkın vaka olmakla birlikte 500 binden fazla kişi hayatını kaybetmiştir. Dünyayı hazırlıksız ve beklenmeyen biranda yakalayan bu küresel salgının ortaya 
çıkardığı zayiat, oldukça büyük ölçeklidir. Küreselleşmenin de etkisiyle tüm dünyaya yayılan salgın, Avrupa Birliği (AB) içinde yıkıcı bir deprem etkisi yaratmış, bir bütün olarak Birlik ve özelde üye devletler bu salgınla mücadelede tam anlamıyla başarı sağlayamamıştır. Soğuk Savaş sonrası tehditlerin boyut değiştirmesi çerçevesinde salt devlet güvenliğini önceliklendiren geleneksel güvenlik yaklaşımlarından devletle beraber birey, çevre, ekonomi, teknoloji gibi unsurların güvenliğini odak noktası hâline getiren yeni güvenlik yaklaşımlarına doğru bir evrilme başlamıştır. Nitekim merkezi odak noktası "insan" olan bu salgın bağlamında yeni güvenlik yaklaşımları ekseninde ortaya konulan insani güvenliğin ne kadar önemli olduğu bir kez daha anlaşılmıştır. Bu minvalden hareketle çalışmada, Covid-19 salgınının AB bağlamında insani güvenliğe olan etkisi doğrultusunda genel bir çerçeve çizilmekle beraber, $\mathrm{AB}$ bütçesine en yüksek katkıyı sağlamaları, Avrupa Parlamentosu'nda en fazla sandalyeye sahip olmaları, askeri güçleri, AB'nin en büyük ekonomileri ve krizden en çok etkilenen devletler olmaları çerçevesinde $\mathrm{AB}$ üye devletlerinden Almanya, Fransa, İtalya ve İspanya bağlamında söz konusu analiz özelleştirilmektedir. Bu yönde bir çalışma oluşturulmasının nihai amacı ise yeni tecrübe edilen Covid-19 salgınını $\mathrm{AB}$ ve insani güvenlik bağlamında analiz ederek Türkçe yazına katkıda bulunmaktadır. İnsani güvenliği merkezine almayan geleneksel güvenlik yaklaşımlarının salgın karşısında etkin olamadığı ve dünyanın en ileri askeri ve ekonomik kapasitesine sahip olan devletlerin dahi salgın karşısında oldukça kırılgan kaldığının tüm dünya tarafından tecrübe edilmesi çerçevesinde, insani güvenliğe etki eden salgınla mücadelede söz konusu üye devletlerin durumu sorunsallaştırılmakta, sayısal veriler ekseninde mevcut durum somutlaştırılmaktadır.

Anahtar Kelimeler: Avrupa Birliği, İnsani Güvenlik, Koronavirüs (Covid-19), Almanya, Fransa, İtalya, İspanya

\section{Giriş}

Dünya genelinde mevcut düzenin yeniden sorgulanmasına yol açan koronavirüs, küresel bağlamda etkiye sebebiyet vermekle beraber, her devleti kendi iç dinamikleri (toplumsal ve kurumsal yapıları gibi) ekseninde de etkilemiştir (Cebeci, 2020: 1411-1412). Diğer yandan, söz konusu virüs devletler açısından en yalın haliyle " kendine yönelik tehditlerin bulunmaması" olarak betimlenen güvenlik ekseninde beka kaygısına yol açmıştır ki bu noktada devletlerin varlıklarının ve bütünlüklerinin devam ettirilmesi ve vatandaşlarının huzur içinde yaşamaları gibi unsurlar ön plana çıkmıştır (Yenal, 2020: 1320). Aralık 2019'a tarihlenen ve ilk kez Çin'in Wuhan şehrinde ortaya çıkan, resmi adıyla Covid- 19 olarak bilinen ve sonuçları itibariyle dünya genelinde derin izler bırakan bu virüs, aynı zamanda insani güvenlik problemine yol açmıştır.

İki kutuplu dünya düzeninden çok kutuplu düzenine evrilen Soğuk Savaş sonrası dönemde dünya politikalarında önemli bir değişim yaşanmaya başlamıştır. Söz konusu değişimlerden biri de güvenlik anlayışına ilişkindir ki bu yeni dönemle beraber tehditlerin boyut değiştirdiği, uluslararası terörizm, organize suçlar, siber tehditler, çevresel tahribatlar, iklim değişikliği, doğal afetler, kitle imha silahlarının yaygınlaşması gibi unsurların güvenliğe yönelik yeni tehditler oluşturduğu görülmektedir. Bu yeni tehditlerden etkilenen artık salt devletler değildir ve bu noktada birey de söz konusu yeni tehditlerden etkilenen aktörler kervanında öncelikli bir konuma yükselmektedir. Bu durum ise insani güvenlik kavramına alan açmaktadır.

İnsani güvenlik kavramı, Soğuk Savaş sonrası uluslararası sistemde yaşanan üç büyük değişikliğe bir cevap olarak görülebilir: 1) Geleneksel tehditlerin boyut değiştirmesi ve yeni tehditlerin ortaya çıkması, 2) Küresel normlarda yavaş ama istikrarlı değişimler yaşanması, 3) Küreselleşme sürecinin etkisi (Sira ve Grans, 2010: 3). Bu noktada Covid-19 salgınıyla insani güvenlik bağlamında mücadelede yönlendirici ve etkin bir rolü ne ölçüde oynadığı konusunda tartışmaların sürdüğü Birleşmiş Milletler ve Dünya Sağlık Örgütü gibi uluslararası kurumlara ek olarak, söz konusu tartışmalar uluslar üstü bir örgüt olan Avrupa Birliği çerçevesinde de salgının başladığı ilk andan itibaren devam etmiştir (Bağbaşlığlu, 2020: 96-97). Ancak Birlik, salgınla mücadelede beklenenin aksine kapsaml, bütüncül, ortak irade ve dayanışma üzerine kurulu bir insani güvenlik yaklaşımı sergileyememiştir. Nitekim Çin'de ortaya çıkıp, hızlı bir şekilde dünyanın tüm coğrafyalarına yayılan bu krizin bilançosu hem $\mathrm{AB}$ genelinde hem de üye devletler 
özelinde son derece ağır olmuş ve bu bağlamda insani güvenliğin ne kadar önemli olduğu alınan derin yaralarla tecrübe edilmiştir.

Avrupa Birliği’nin en önemli üyeleri olan Almanya, Fransa, İtalya ve İspanya ekseninde Covid-19 salgınını insani güvenlik bağlamında analiz eden bu çalışma zarfinda, öncelikle insani güvenliğe yönelik kavramsal bir çerçeve doğrultusunda ilgili literatürde ortaya konan insani güvenlik tanımları ele alınmaktadır. Akabinde, tarihsel bir perspektiften AB'nin insani güvenliğe ilişkin söylemi analiz edilmektedir. Son bölümde ise AB bağlamında Covid-19 virüsünün insani güvenliğe olan etkisi doğrultusunda genel bir çerçeve ortaya konulmakla beraber, AB bütçesine en yüksek katkıyı sağlamaları, Avrupa Parlamentosu'nda en fazla sandalyeye sahip olmaları, askeri güçleri, AB'nin en büyük ekonomileri, virüsle mücadelede farklı başarı düzeylerine sahip ve krizden en çok etkilenen devletler olmaları çerçevesinde AB üye devletlerinden Almanya, Fransa, İtalya ve İspanya özelinde söz konusu virüsün insani güvenliğe yönelik yansıması analiz edilmektedir.

\title{
1. Kavramsal Çerçeve: İnsani Güvenlik
}

İki kutuplu dünya sisteminin sona erdiği Soğuk Savaş sonrası dönemin yarattı̆̆ yeni dünya kompozisyonunda ve küreselleşmenin de doruk noktasına ulaşmasıyla salt devletleri ve bu noktada ulusal ve askeri güvenliği odak noktasına koyan geleneksel güvenlik yaklaşımlarında önemli bir değişim yaşanmıştır. Bu noktada artık güvenlik sadece devlet merkezli ele alınmayıp, analize devlet dış1 aktörler ve yeni sektörler de dâhil edilmektedir. Mevzubahis bu durum ise insani güvenlik kavramına alan açmaktadır.

Soğuk Savaşın sona ermesiyle beraber iç silahlı çatışmaların, etnik çatışmaların niceliksel olarak artması ile devlet merkezli tehditlerin insan merkezli tehditlere evrilmesi, sınır aşan yeni tehditlerle mücadelede bireylerin de güvenliğinin sağlanması gerekliliğinin belirginleşmesi, bireyin güvenliğini önceleyen uluslararası normlar ve ilkelerin ortaya çıkması çerçevesinde hem geleneksel güvenlik anlayışında değişim yaşanmış hem de insani güvenlik kavramı ön plana çıkmıştır (Ovalı, 2006: 17). Bu bağlamda, Birleşmiş Milletler (BM) tarafından 1994 yılında yayımlanan "Kalkınma Raporu'nda (Human Development Report)" geleneksel güvenlik anlayışında yaşanan değişime yönelik ortaya konan şu ifadeler önem arz etmektedir:

\begin{abstract}
"Güvenlik kavramı, çok uzun bir süredir ülkenin dış saldırganlıklardan bertaraf edilmesi, dış politikada ulusal çıkarların korunması ve nükleer tehditler karşısında küresel güvenliğin temin edilmesi şeklinde dar bir perspektiften tanımlanmıştır. Öyle ki söz konusu kavram, bireyden ziyade ulus-devletlerle ilişkilidir. Bu noktada süper güçler Soğuk Savaşın ürünü olan ideolojik mücadeleye yoğunlaşmıştır. Sadece son zamanlarda bağımsızlıklarını kazanan gelişmekte olan devletler, kırılgan ulusal kimliklerine yönelik gerçek veya algılanan tehditlere karşı duyarlı davranma eğiliminde olmuştur. Ancak unutulan realite, günlük yaşamlarında güvenlik arayışında olan sıradan insanların somut endişeleridir. Bu insanların çoğu için güvenlik; hastalık, açlık, işsizlik, suç, sosyal çatışma, siyasi baskı ve çevresel tehditlerden korunmayı sembolize etmektedir. Soğuk Savaşın karanlık gölgeleri ortadan kalktığında artık birçok çatışmanın uluslar arasında değil uluslar içinde olduğu görülebilecektir” (UN Human Development Report, 1994: 22).
\end{abstract}

Kalkınma Raporu'nda da ortaya konduğu gibi Soğuk Savaş sonrası dönemin güvenlik anlayışının salt ulus devlet eksenli olmayıp, tehditlerin çevreden açlığa, hastalıklardan siyasi baskılara kadar geniş bir skala doğrultusunda çeşitlendiği ve bu eksende bireyin de dâhil olduğu yeni bir güvenlik anlayışına işaret edildiği görülmektedir. Öte yandan, insani güvenlik kavramına yönelik ortak bir tanımda buluşulması sorunu yaşansa da söz konusu kavram aynı rapor ekseninde tanımlanmaktadır. Bu noktada "insanların öncelikle açlık, hastalık gibi kronik tehditlerden, günlük yaşamı etkileyen ani ve zarar verici dalgalanmalardan korunması ve topyekûn insan özgürlükleri ve gereksinimliklerinin korunması ve yerine getirilmesi, " (UN Human Development Report, 1994: 4,

Turkish Studies, 15(6) 
23) olarak BM Kalkınma Raporu'nda ilk kez kavramsal bir çerçeveye oturtulan insani güvenliğin, "korkudan arınma" (freedom from fear) ve "yoksulluk ve yoksunluktan arınma" (freedom from want) şeklinde iki temel mekanizmayı kapsadığı belirtilmekle beraber, kavramın diğer unsurları ise şu şekilde ortaya konmaktadır:

1) Ekonomik Güvenlik: Bireylere yönelik üretken ve kazançlı bir işten veya kamu tarafından finanse edilen temel bir gelirin sağlanmasıdır.

2) Sağlık Güvenliği: İnsan sağlığını etkileyen tüm hastalıklardan ve sağlıksız yaşam koşullarından bireyin asgari düzeyde korunmasıdır.

3) Gıda Güvenliği: Tüm insanların her zaman fiziksel ve iktisadi olarak temel gıdaya ulaşımının sağlanmasıdır.

4) Çevresel Güvenlik: Tüm insanların çevrenin zarar verici etkilerinden, doğaya etki eden insan kaynaklı tahribatlardan ve çevresel ortamın bozulması kaynaklı ortaya çıkan sorunlardan korunmasidır.

5) Kişisel Güvenlik: İnsanların vatandaşı olduğu devletlerden veya diğer devletlerden, bireylerden, grupların şiddetinden ve özel boyutta bireyin kendi evi içinde aile bireyleri kaynaklı kötü davranış ve şiddetten korunmasıdır.

6) Toplum Güvenliği: İnsanların mezhepsel ve etnik şiddetten korunmasının temin edilmesidir.

7) Siyasi Güvenlik: İnsanların temel insan hakları ihlallerinin, siyasi baskının olmadığ1 ve özgürlüklerin korunduğu bir toplum içinde yaşamasının sağlanmasıdır (UN Human Development Report, 1994: 25-33;Tangör, 2012: 62; Y1lmaz, 2017: 431; Liotta ve Owen, 2006a: 42; Breslin ve Christou, 2015: 2; Aksu ve Turhan, 2012: 76).

Diğer taraftan ilgili literatür analiz edildiği takdirde, Birleşmiş Milletler Kalkınma Programı ekseninde geliştirilen "Kalkınma Raporu" bağlamında ortaya konan insani güvenliğe ilişkin kavramsal bir çerçeve sunulduğu görülmektedir. Örneğin, Jorge Nef (1999) insani güvenliği çevresel, bireysel ve fiziksel güvenlik; ekonomik güvenlik; sosyal güvenlik; siyasi güvenlik ve kültürel güvenlik şeklinde beş kategorizasyon ekseninde tanımlamaktadır (25). Söz konusu kavram, Laura Reed ve Majid Tehranian tarafından bireyler arası ilişkileri ve saygı faktörünü güçlendirici koşulları vurgulayan psikolojik ve iletişimsel güvenlik bağlamında tanımlanırken ( Reed ve Tehranian'dan akt., Paris, 2001:91-92) Robert Bedeski (2000) ise insani güvenliğin insan yaşamını koruyan ve savunan kurumları, teknolojiyi ve faaliyetleri içerdiğini ve insan özgürlüğünün garanti altına alınmasında rol oynayan barış ve refahın korunması süreci olduğunu vurgulamaktadır. Caroline Thomas (1999) ise insani güvenliğin, tüm insanlığın ortak yararı vurgusuyla temel ihtiyaçların karşılanması, insanlık onuruna saygı, küresel, ulusal ve/veya yerel güçlerin bireye yönelik baskıcı güçlerinin olmaması durumunu ifade ettiğini belirtmektedir $(3,6)$. Öte yandan, tablo 1 kavrama yönelik ilgili literatürdeki kavramsallaştırmaların daha analitik bir düzeyde ele alınmasını yansıtmaktadır. 
Tablo 1: İnsani Güvenlik Yaklaşımları

\begin{tabular}{|c|c|c|c|c|}
\hline Kişi & Referans Nesnesi & Temel Değerler & Tehditler & $\begin{array}{l}\text { Güvensizlik } \\
\text { Durumundaki } \\
\text { Aktörler }\end{array}$ \\
\hline Kofi Annan & Birey & $\begin{array}{l}\text { Ekonomik kalkınma, } \\
\text { sosyal adalet, } \\
\text { çevrenin korunması, } \\
\text { demokratikleşme, } \\
\text { silahsızlanma ve } \\
\text { insan haklarına saygı } \\
\text { ve hukukun } \\
\text { üstünlüğ̈ü }\end{array}$ & $\begin{array}{l}\text { Şiddet, nükleer ve } \\
\text { kitle imha silahları, } \\
\text { baskı, insan hakları } \\
\text { ihlalleri, sivil } \\
\text { nüfusun yer } \\
\text { değiştirmesi, } \\
\text { uluslararası } \\
\text { terörizm, AIDS } \\
\text { pandemisi, } \\
\text { uyuş̧turucu ve } \\
\text { silah kaçakçıllı̆̆1, } \\
\text { çevresel felaketler }\end{array}$ & $\begin{array}{l}\text { Devletler, bireyler, } \\
\text { doğa ve çevre }\end{array}$ \\
\hline Sadako Ogato & Birey & $\begin{array}{l}\text { 1-Devletler ve } \\
\text { vatandaşlar } \\
\text { çatı̧̧aları barış̧ıl } \\
\text { ve şiddet içermeyen } \\
\text { yollarla çözme ve } \\
\text { çatı̧malardan sonra } \\
\text { uzlaşma çabalarını } \\
\text { etkin bir şekilde } \\
\text { yürütme yeteneğine } \\
\text { haiz olmalıdır. } \\
\text { 2- İnsanlar; bir } \\
\text { devlete ait olan } \\
\text { insani, siyasi, sosyal, } \\
\text { ekonomik ve kültürel } \\
\text { haklar da dâhil } \\
\text { olmak üzere tüm hak } \\
\text { ve yükümlülükleri } \\
\text { ayrım gözetmeksizin } \\
\text { kullanmalıdır. } \\
\text { 3- Sosyal içerme } \\
\text { veya politik, sosyal } \\
\text { ve ekonomik politika } \\
\text { yapma süreclerine } \\
\text { eşit erişimin } \\
\text { sağlanması ve } \\
\text { bunlardan eşit } \\
\text { faydaların alınması } \\
\text { gerekmektedir. } \\
\text { 4-Hukukun } \\
\text { üstünlüğünün } \\
\text { oluşturulması ve } \\
\text { adalet sisteminin } \\
\text { bağımsızlı̆ı̆. Bir } \\
\text { toplumdaki her birey } \\
\text { aynı hak ve } \\
\text { yükümlülüklere } \\
\text { sahip olmalı ve aynı } \\
\text { kurallara tabi } \\
\text { olmalıdır. }\end{array}$ & $\begin{array}{l}\text { Siyasi } \\
\text { Askeri } \\
\text { Sosyal } \\
\text { Ekonomik } \\
\text { Cevre } \\
\text { Silahlanma } \\
\text { Uyusturucu ticareti } \\
\text { HIV Yayılması }\end{array}$ & $\begin{array}{l}\text { Doğa, çevre, } \\
\text { devletler, bireyler, }\end{array}$ \\
\hline Ramesh Thakur & Toplum & İnsani güvenlik, bir & Bireyin "yaşam & Devlet, bireyler, \\
\hline
\end{tabular}

Turkish Studies, 15(6) 


\begin{tabular}{|c|c|c|c|c|}
\hline & & $\begin{array}{l}\text { toplumun yaşam } \\
\text { kalitesini ifade eder. } \\
\text { İnsani güvenliğin ana } \\
\text { unsuru insan } \\
\text { haklarıdır. }\end{array}$ & $\begin{array}{l}\text { kalitesini bozan } \\
\text { her şey" }\end{array}$ & $\begin{array}{l}\text { toplumsal gruplar, } \\
\text { idari, yarg1, polis, } \\
\text { doğa, çevre }\end{array}$ \\
\hline $\begin{array}{l}\text { Hans Van Ginkel } \\
\text { and Edward } \\
\text { Newman }\end{array}$ & Birey & İnsanlık onuru & $\begin{array}{l}\text { Korku, çatışma, } \\
\text { cehalet, yoksulluk, } \\
\text { sosyal ve kültürel } \\
\text { yoksunluk, açlik }\end{array}$ & Devletler, bireyler \\
\hline Kanti Bajpai & Birey & $\begin{array}{l}\text { Bireysel güvenlik ve } \\
\text { özgürlük }\end{array}$ & $\begin{array}{l}\text { Doğrudan: şiddet, } \\
\text { ayrımcılık, } \\
\text { uluslararası } \\
\text { anlaşmazlıklar, } \\
\text { silahların } \\
\text { yayılması } \\
\text { Dolaylı: yoksulluk, } \\
\text { hastalık, doğal ve } \\
\text { insan kaynaklı } \\
\text { felaketler, çevresel } \\
\text { bozulma }\end{array}$ & $\begin{array}{l}\text { Devletler, devlet- } \\
\text { dişı aktörler }\end{array}$ \\
\hline Lincoln Chen & Birey & $\begin{array}{l}\text { İnsanın hayatta } \\
\text { kalması, refahı ve } \\
\text { özgürlüğü }\end{array}$ & $\begin{array}{l}\text { Yoksulluk, savaş, } \\
\text { çatışma, baskı }\end{array}$ & $\begin{array}{l}\text { Devletler, bireyler, } \\
\text { çevre }\end{array}$ \\
\hline $\begin{array}{l}\text { Gary King ve } \\
\text { Christopher } \\
\text { Murray }\end{array}$ & Birey & $\begin{array}{l}\text { Yoksulluğun önüne } \\
\text { geçilmesi, refah, } \\
\text { gelir, sağlık, eğitim, } \\
\text { siyasi özgürlük }\end{array}$ & $\begin{array}{l}\text { Baskı, yoksulluk, } \\
\text { suç, askeri } \\
\text { çatışma, } \\
\text { hastalıklar, akut } \\
\text { çevre sorunları, } \\
\text { ekonomik krizler }\end{array}$ & $\begin{array}{l}\text { Devlet, birey, } \\
\text { çevre, dünya } \\
\text { ekonomisi, ordu }\end{array}$ \\
\hline Caroline Thomas & Birey & $\begin{array}{l}\text { Gıda, barınma, } \\
\text { eğitim, sağlık } \\
\text { alanlarında } \\
\text { yetersizlik, siyasi } \\
\text { katılım ve temsil }\end{array}$ & $\begin{array}{l}\text { Baskı, siyasi } \\
\text { katılım, temsil ve } \\
\text { temel ihtiyaç } \\
\text { eksikliği }\end{array}$ & Birey, devlet \\
\hline George Macleon & Birey & $\begin{array}{l}\text { Bireylerin } \\
\text { kendilerinin, } \\
\text { çevrelerinin ve içinde } \\
\text { bulundukları } \\
\text { toplumun güvenliği }\end{array}$ & Kıtlık, kitlesel göç & Birey, devlet \\
\hline Jennifer Leaning & Birey ve Toplum & $\begin{array}{l}\text { Maddi, sosyal ve } \\
\text { psikolojik koşulların } \\
\text { yaratılması }\end{array}$ & $\begin{array}{l}\text { Yaşama, korunma, } \\
\text { psiko-sosyal } \\
\text { ihtiyaçlara yönelik } \\
\text { tehditler, } \\
\text { toplumsal } \\
\text { bozulma, düşük } \\
\text { yaşam standardı, } \\
\text { savaş }\end{array}$ & $\begin{array}{l}\text { Birey, devlet, } \\
\text { toplum }\end{array}$ \\
\hline
\end{tabular}

\section{Kaynak: (GTRC, t.y).}

Bu noktada insani güvenlik bağlamında birey, toplum, ekonomi, çevre, sağlık ve gıda gibi koşulların odak noktası yapıldığı görülmektedir. Öyle ki insani güvenlik kavramı, geleneksel güvenlik sorunlarının ötesinde bir anlayışla çevrelenen güvenlik konsepti bağlamında ortaya çıkan bir paradigmadır. $\mathrm{Bu}$ paradigma salt ulus devletlere odaklanmak yerine güvenliğe uluslararası ilişkiler, stratejik çalışmalar ve insan haklarını içeren multi-disipliner bir perspektif ile bakmaktadır 
(Ataman, 2020). Öte yandan, insani güvenlik bağlamında odak noktasının başta birey ve toplum olduğu, bu noktada devletle beraber kişilerin ve toplumun korunmasının ve insan yaşamına engel olan tüm tehditlerin bertaraf edilmesinin altı çizilmektedir ki bu durum ise insani güvenliğe yönelik tehditlerin neler olduğu sorusunun analiz edilmesini gerektirmektedir (Ovalı, 2006: 20). İnsani güvenliğine yönelik tehditleri doğrudan ve dolaylı olarak iki grup ekseninde kategorileştiren Bajpai'ye göre (2000), ölümlere ve sakatlanmalara neden olan şiddet (kadınların, çocukların öldürülmesi, cinsel şiddet, katliam, soykırım, savaş sonucu ölümler gibi), insanlık dışı muameleler ( kadın ve çocuk kaçakçılığı, aile içi fiziki taciz, adam kaçırma, muhaliflere yönelik baskı, yargı sürecine müdahale ve kölelik gibi), uyuşturucu bağımlılığı, ayrımcılık ve baskı, devletlerarası çatışmalar, kitle imha, konvansiyonel ve hafif silahlar, insani güvenliğe yönelik doğrudan tehditleri oluştururken dolaylı tehditler ise gıda, sağlık, eğitim, temiz içme suyu gibi temel ihtiyaçların karşılanmaması, insan hayatını tehdit eden hastalıklar, doğal ve insan kaynaklı afetler, nüfus değişimleri ve çevresel tahribatlar gibi unsurlardan oluşmaktadır (20).

Sonuç olarak hem güvenliğin genişleyen yeni doğası hem de ortaya konan tanımlamalar ve boyut değiştiren yeni tehdit skalası ekseninde insani güvenlik nihai olarak birey odaklı olmakla birlikte, içerisinde topluma yönelik atıfları ve multi-disipliner bir yaklaşımı da barındırmakta ve genel bir çerçeve doğrulusunda insani güvenliğe etki edecek her türlü tehditten bireylerin korunmasını ifade etmektedir.

\section{Geçmişten Günümüze Avrupa Birliği’nin İnsani Güvenlik Söylemi}

Avrupa Birliği’nin güvenlik ve savunma politikasının gelişimi içerisinde insani güvenlik kavramı yeni bir alanı teşkil etse de söz konusu kavramın son dönemlerde önemli bir söylem olarak Birlik bağlamında ön plana çıktığı görülmektedir.

Avrupa Birliği’nin insani güvenlik söylemine ilişkin üç temel belgesi bulunmaktadır. Bunlardan ilki, 2003 yılında yayımlanan Avrupa Güvenlik Strateji Belgesi'dir. Söz konusu belgede ve 2008 y1lında ortaya konan bu belgenin uygulama Raporu'nda AB'nin öncelikli hedefinin insani güvenlik olduğu, bunun sağlanması için yoksulluğun azaltılması, eşitliğin ve kalkınmanın sağlanması ve insan hakları ihlallerinin önlenmesi gibi hususlarda çalışılması gerekliliğinin altı çizilmektedir (European Security Strategy, 2003; European Security Strategy, 2009).

Öte yandan, AB'nin insani güvenlik söyleminin ilk kez daha somut anlamda hayata geçmesi, Avrupa'nın güvenlik mekanizması ve kapasitesi üzerine çalışan akademik bir grup tarafından yayımlanan rapor ekseninde gerçekleşmiştir. Söz konusu rapor, 2004 yılında yayımlanan "Barselona Raporu” bağlamında geliştirilmiş ve odak noktasına "Avrupa İçin İnsani Güvenlik Doktrini" konularak, Birlik bağlamında insani güvenlik söyleminin güçlendirilmesi hususu tartışılmaya başlanmıştır. Bu noktada AB'nin güvenlik ve dış politikasına uyumlu bir insani güvenlik konsepti geliştirilmeye çalışılmıştır (Kotsopoulos, 2006: 7). AB'nin faaliyetleri çerçevesinde küresel güvenliği sağlamakla yükümlü olduğu ve bunun için insani güvenliği ön plana alması gerekliliğini vurgulayan raporda insani güvenlik, insan hakları ihlallerinin neden olduğu güvensizlik ortamından bireyleri kurtarma olarak tanımlanmakta ve geleneksel devlet temelli yaklaşımlardan, bireyi ve insan haklarını öncülleyen bir yaklaşımın benimsenmesinin önemine değinilmektedir (Albrecht vd., 2004: 5, 14). Ayrica Barselona Rapor'unda AB'nin neden insani güvenlik yaklaşımını benimsemesi gerektiğinin gerekçeleri üç ana başlık altında toplanmaktadır. Bir diğer ifadeyle, $A B$ 'nin insani güvenlik söyleminin üç motivasyon kaynağ 1 üzerine temellendiği ifade edilmektedir. Bunlardan ilki, insan hayatının değerine yönelik vurgu doğrultusunda, AB'nin temel güvenlik ihtiyaçlarından yoksun veya güvenlik tehdidi yaşayan $A B$ vatandaşlarına ve üye devletlere yardım sağlamasına dayanan etik anlayıştır. İkincisi, AB'nin insani güvenliği benimsemesinde yasal bir taahhüdünün söz konusu olmasıdır. Bu bağlamda uluslararası hukuka göre, $A B$ sadece kendi vatandaşları değil, güvenlik politikaları çerçevesinde tüm insanlar için güvenliği sağlamakla yükümlüdür. $\mathrm{AB}$ Müktesebatı içerisinde yer alan belgelerde $\mathrm{AB}$ 'nin insani güvenlik konusundaki yasal yükümlülüklerinin çerçevesi belirlenmiştir. Ü̧çüncüsü ise Birliğin

Turkish Studies, 15(6) 
kendi çıkarlarını koruma arayışının bir parçası olarak insani güvenliği benimsemesidir ki (Sira ve Grans, 2010: 4-5; Glasius ve Kaldor, 2005: 62-82) bu noktada devreye Avrupa dışındaki insanların güvensizlik içinde olmaları durumunun Avrupa'ya yansıyacağ 1 görüşü girmektedir (Albrecht vd., 2004: 5). Tüm bunlara ek olarak, insani güvenliğe olan gereksinimin nihai sebebi olarak değişen dünya düzeni ve artık çatışmaların devletlerarasında değil onların içinde cereyan ederek, insanları doğrudan etkilediği gösterilmektedir (Albrecht vd., 2004: 4). Mevzubahis rapora ilişkin belirtilmesi gereken bir diğer husus ise farklı perspektifler doğrultusunda yapılan değerlendirmelerin bulunmasıdır. $\mathrm{Bu}$ bağlamda, bazı yazarlar raporun insani güvenliğe dar bir bakış açısıyla yaklaştığını ifade ederken (Albercht vd., 2004: 8) bazıları ise insan hakları ihlallerini önleme ve şiddet içermeyen tehditlere karşı insani güvenliğin sağlanmasına yönelik müdahalelerde bulunulmasına işaret ederek, raporun insani güvenliğe geniş bir açıdan yaklaştı̆̆ını belirtmektedir (Liotta ve Owen, 2006b: 94).

AB'nin insani güvenlik yaklaşımına ilişkin bir diğer belgesi Madrid Raporu'dur. 2007 yılında İnsani Güvenlik Çalışma Grubu tarafından yayımlanan rapor, AB bağlamında insani güvenlik yaklaşımının daha da geliştirilmesi ve Barselona Raporu çerçevesinde altı çizilen söz konusu kavramın kurumsal düzeye çıkarılması amacını taşımaktadır. Ayrıca, insani güvenliğin bireylerin ve toplumun temel ihtiyaçlarıyla ilgili olduğunu, sokakta kendini güvende hissetmenin yanı sıra maddi olarak hayatta kalma ve özgür olmaya işaret ettiğini, insanların refah ve barış içinde yaşamaları için korkudan, yoksulluktan ve yoksunluktan arınmayı içerdiğini vurgulayan rapor (Albercht vd., 2007: 3) Barselona Raporuna kıyasla insani güvenliği geniş bir perspektiften ele almaktadır. Öte yandan, söz konusu rapor ekseninde iki önemli öneri ortaya konmaktadır. Bunlardan ilki, insani güvenliğin sağlanmasına ilişkin ilkelerin tüm üye devletlerin imzalayacağı bir deklarasyonla daha somut bir zemine taşınmasıdır. Mevzubahis deklarasyonun, AB'nin ne zaman ve hangi krizlere müdahale edeceği konusunda $A B$ kurumlarına kılavuz görevi ifa etmesi gerekliliğinin altı çizilmektedir. İkinci öneri ise insani güvenliğin sağlanması için belirlenen ilkelerin farklı koşulları içermesiyle ilgilidir (Albrecht vd., 2007: 24-25).

$\mathrm{AB}$ ve insani güvenlik denkleminde söz konusu bu temel belgelere ek olarak, somut anlamda olmasa da $A B$ 'nin ortak diş ve güvenlik politikasının bir parçası olarak insani güvenliğe yapılan atıf çerçevesinde 2016 yılında yayımlanan "Avrupa Küresel Strateji” belgesi de önem arz etmektedir ki bu belgede bütünleşmiş bir yaklaşımla insani güvenliğin güçlendirilmesi gerekliliği vurgulanmaktadır (European Global Security Strategy, 2016).

Sonuç olarak, AB bağlamında insani güvenlik, Birliğin farklı krizlerde (hem çatışmalar içerisindeki şiddetin sonuçlarından muzdarip olan insanlara hem de tsunami ve kıtlık gibi felaketlerde) insan ihtiyaçlarını karşılamasıyla ilgilidir. Bu noktada insani güvenliği sağlamak, hem fiziksel koşulların sağlanması hem de maddi refah ile ilgili bir durumu yansıtmaktadır (Albercht vd., 2007: 8).

\section{Covid-19 Süreci ve Avrupa Birliği: İnsani Güvenlik Sorunsalı}

Tarihsel bir perspektiften, 14. Yüzyılda Avrupa'da ekonomik, sosyal ve siyasi açıdan büyük bir felakete yol açan ve insanlığın varoluşuna tehdit olan en ölümcül salgınlardan biri Kara Veba idi. Çağdaş dünyada tecrübe edilen İspanyol gribi ise (1918-1920) dünya nüfusunun yaklaşık üçte birini enfekte etti. İspanyol gribinden sonra yaşanan en büyük pandemi olan ve literatürde resmi adı SARS-CoV-2 olarak geçen kamuoyunda koronavirüs olarak bilinen Covid-19 salgını ise cinsiyet, yaş, dil, din, etnik köken ve sınıf ayrımı yapmayan tüm insanlığa yönelmiş ve tüm dünyayı hazırlıksız yakalayan küresel bir tehdittir.

İlk olarak, 2019 Aralık ayında Çin'de Hubei eyaletine bağlı ve 11 milyon nüfusa sahip Wuhan şehrindeki deniz ürünleri pazarında bulunan insanlarda görülen Covid-19, hızla insandan insana bulaşarak tüm dünyaya yayılmıştır (TÜBA, 2020: 26). Virüsün şeffaf bir yönetim yapılanmasına sahip olmayan Çin'in Wuhan kentinde ortaya çıkması, söz konusu tehdide yönelik 
dünya genelinde bilgi eksikliğine neden olmuş, bu ise krizin küresel ölçekte yayılmasını tetiklemiştir. Topyekûn uluslararası ilişkilere, ekonomiye, siyasete ve sosyal faktörlere olumsuz yönde etki eden salgının, $\mathrm{AB}$ genelinde ve üye devletler özelinde insan hayatını etkileyerek insani güvenliğe ilişkin büyük bir tehdide sebebiyet verdiği görülmektedir.

AB Komisyonu Başkanı Ursula von der Leyen tarafindan ortaya konan bir makalede, "Avrupa'nın bilinmeyen bir düşman ve benzeri görülmemiş bir kriz ile beklenmedik bir anda karş1 karşıya kalındığını” vurgulanmaktadır (Başay, 2020). Benzer şekilde eski Komisyon Başkanı Jacques Delors, Birliğin ölümcül bir tehditle karşı karşıya olduğunu ifade etmektedir (Mcquinnes, 2020). Tüm bu söylemler doğrultusunda Başkan Ursula von der Leyen'in birçok farklı eylem biçimini bir araya getiren ve üç ana sütundan ${ }^{1}$ oluşan bir koronavirüs müdahale ekibini kurmasına ek olarak üye devletleri, ulusal stratejileri bağlamında ve salgının farklı aşamalarında test araçlarını etkili bir şekilde kullanmaları konusunda desteklemeyi amaçlayan önerilerin Komisyon tarafından sunulması, mevcut araştırma verilerinin hızlı bir şekilde toplanması ve paylaşılmasını sağlamak için bir Avrupa Covid-19 Veri Platformu'nun Komisyon aracılığıyla başlatılması, insani yardım çalışanlarını ve koronavirüs müdahalesi için acil durum malzemelerini dünyanın en kritik bölgelerinden bazılarına taşımak için bir $A B$ İnsani Hava Köprüsü'nün Komisyon tarafından kurulması ve Covid-19'a karşı aşıların geliştirilmesini, üretilmesini ve uygulanmasını hızlandırmak için bir Avrupa stratejisinin Komisyon tarafindan sunulması Avrupa Komisyonu tarafindan atılan önemli adımları teşkil etmektedir (European Commission, 2020a). Öte yandan, Avrupa Hastalık Önleme ve Kontrol Merkezi'nin ${ }^{2}$ söz konusu salgına yönelik verileri düzenli olarak güncellemesi çerçevesinde ortaya konulan risk değerlendirmesi ile farkındalığı artırmaya dönük faaliyetleri (European Centre for Disease Prevention and Control- ECDC) ise ayrica önem arz etmektedir. Ancak tüm bu önemli adımlara rağmen mevzubahis salgın $\mathrm{AB}$ çerçevesinde büyük bir hasara sebebiyet vermiştir. $\mathrm{AB}$ bağlamında ciddi oranda zayiata neden olan salgının yarattığı mevcut durum ise tablo 2'de görülmektedir.

\footnotetext{
${ }^{1}$ İlk sütun; önleme, tedarik ve yardım önlemleri üzerinde çalışan tıp alanını kapsamaktadır. İkinci sütun; ulaşım, seyahat ve Schengen ile ilgili hususları içermektedir. Üçüncü sütun ise turizm, ulaşım ve ticaret gibi çeşitli alanların yanı sıra değer zincirleri ve makro ekonomi gibi çeşitli iş sektörlerine derinlemesine bakarak ekonomiyi kapsamaktadır (European Commission, 2020b).

${ }^{2}$ Söz konusu merkez 27 AB üyesini içeren, Avrupa'nın salgın hastalıklara karşı korunmasına ilişkin önlemler alan bağımsız bir Avrupa Birliği kuruluşudur (ECDC, 2020).
} 
Tablo 2: AB Bağlamında Covid-19 Bilançosu (28 Haziran 2020)

\begin{tabular}{|c|c|c|c|}
\hline Devletler & Toplam Vaka & İyileşen & Ölüm \\
\hline İsveç & 65.137 & - & 5.280 \\
\hline Belçika & 61.312 & 16.941 & 9.733 \\
\hline Hollanda & 50.143 & - & 6.107 \\
\hline Portekiz & 41.189 & 26.864 & 1.561 \\
\hline Polonya & 34.033 & 19.972 & 1.441 \\
\hline Romanya & 26.347 & 18.530 & 1.599 \\
\hline İrlanda & 25.460 & 23.349 & 1.738 \\
\hline Avusturya & 17.522 & 16.348 & 698 \\
\hline Danimarka & 12.675 & 11.508 & 604 \\
\hline Çekya & 11.038 & 7.688 & 349 \\
\hline Finlandiya & 7.191 & 6.600 & 328 \\
\hline Bulgaristan & 4.408 & 2.370 & 211 \\
\hline Lüksemburg & 4.217 & 3.968 & 110 \\
\hline Macaristan & 4.146 & 2.685 & 584 \\
\hline Yunanistan & 3.343 & 1.374 & 191 \\
\hline Hirvatistan & 2.624 & 2.150 & 107 \\
\hline Estonya & 1.986 & 1.797 & 69 \\
\hline Litvanya & 1.813 & 1.501 & 78 \\
\hline Slovakya & 1.643 & 1.455 & 28 \\
\hline Letonya & 1.112 & 932 & 30 \\
\hline Kıbris & 992 & 824 & 19 \\
\hline Malta & 670 & 632 & 9 \\
\hline
\end{tabular}

Kaynak: (Coronavirus Update'den elde edilen verilerle yazarın kendisi tarafindan oluşturulmuştur).

Söz konusu küresel salgın; tarihsel olarak bütünleşme süreci 13. Yüzyıla kadar götürülebilse de somut anlamda bir birlik kurulması fikrinin II. Dünya Savaşı sonrasında güçlenmesiyle ortaya çıkan Avrupa Birliği mekanizması içerisinde önem arz eden iş birliği ve dayanışmanın ${ }^{4}$ Birlik içinde ne kadar kırılgan olduğunu gözler önüne sermiş ve tüm dünyada olduğu gibi $\mathrm{AB}$ özelinde de insani bir krize dönüşmüş ve bu noktada insani güvenliğin sağlanmasında hem AB'nin hem de üye devletlerin ne kadar hazırlıksız olduğu ve yetersiz kaldığı görülmüştür. Nitekim bu durum AB'nin en önemli üyeleri olan Almanya, Fransa, İtalya ve İspanya özelinde de yaşanmıştır. Bir diğer ifadeyle Birlik bazında salgınla mücadelede yeterli dayanışma ve iş birliği sağlanamamış, diğer üye devletlerle beraber Almanya, Fransa, İtalya ve İspanya da kendi ülkeleri içerisinde mücadele odaklı bir yaklaşım ortaya koymuş ancak bu mücadelede somut başarı sağlayamamıştır. Aslında her ne kadar Almanya'nın pandemiyle mücadelede etkinlik ölçeği diğer devletlere kıyasla başarı eksenli olsa da insani güvenliğin tesisinde Almanya'nın bile sorunlara gebe kaldığı görülmektedir. Fransa, İtalya ve İspanya çerçevesinde ise bu durum oldukça menfi şekilde tezahür etmektedir. Nitekim söz konusu bu üç devlet bağlamında sağlık hizmetleri mekanizmasının etkin anlamda işlememesi, şekil 1-3 arasında görüldüğü üzere salgının öncelikle etki ettiği yaşlı nüfus oranının genç nüfusa kıyasla yüksek olması ve salgınla mücadeleye dönük tedbirlerin geç alınmaya başlanmass ${ }^{5}$, salgınla mücadelede başarı düzeyinin sağlanamamasına

${ }^{3}$ Tablo 3'de belirtilmesi nedeniyle tablo 2 Almanya, Fransa, İtalya ve İspanya'ya ait verileri içermemektedir.

${ }^{4} \mathrm{AB}$ bütünleşme sürecinde önem arz eden dayanışma hükmünün ilk izleri, bütünleşmenin çıkış noktası olan 9 Mayıs 1950'de ilan edilen "Schuman Bildirisi'nde" görülmektedir: "Kömür ve çelik üretiminde kurulacak dayanışma, Fransa ve Almanya arasında çıkabilecek bir savaşı imkânsız hâle getirecektir"(Schuman Decleration, 1950). Öte yandan güvenlik bağlamında dayanışma hükmü, AB'nin İşleyişine Dair Antlaşmada vurgulanarak, bir üye devletin terörist bir saldırı veya doğal ya da insan kaynaklı bir felaket ile karşı karşıya kalması durumunda $A B$ ve üye devletlerin ellerindeki tüm kaynakları seferber ederek söz konusu devlete yardım edeceğinin altı çizilmektedir (Md. 222-1).

${ }^{5}$ Fransa' da ilk vaka 27 Aralık 2019 günü görülmekle (Ntv, 2020) beraber, önlemlerin alınmaya başlandığı ilk tarih 16 Mart 2020'dir (Euronews, 2020). Öte yandan, İspanya'da 31 Ocak 2020 tarihinde ilk vaka açılaması yapılmakta 
sebebiyet vermiştir. Tüm bunlara ek olarak, $\mathrm{AB}$ bağlamında ortak bir sağlik politikasının olmaması, bu alandaki yetkilerin devletler düzeyinde olması çerçevesinde bir bütün olarak Birlik, sorunla mücadele etkili olamamış ancak belirtildiği gibi devletler de somut başarı düzeyini sağlayamamıştır. Öte yandan, Birlik çerçevesinde altı çizilmesi gereken bir diğer husus ise sağlıkla ilgili ürünlerin $\mathrm{AB}$ içerisinde üretilmemesidir. Nitekim Joseph Borrel'in ele aldığı makalede maske'lerin \%50'sinin, penisilinin \%90'nının, antibiyotik ihtiyacının \%40'ının Çin'den ithal edildiği ve parasetamol içeren ilaçların Birlik içinde üretilmediğinin altı çizilmektedir (Borrel, 2020). Birliğin sağlık sektörü bazlı yaşadığı bu sorunla beraber, üye devletlerin tıbbi ekipman tedarikini ve ihracatını salgın nedeniyle yasaklamaları çerçevesinde malların, hizmetlerin, sermayenin ve kişilerin serbest dolaşımına dayalı ortak pazar mekanizmasının işlerliği de yara almıştır.

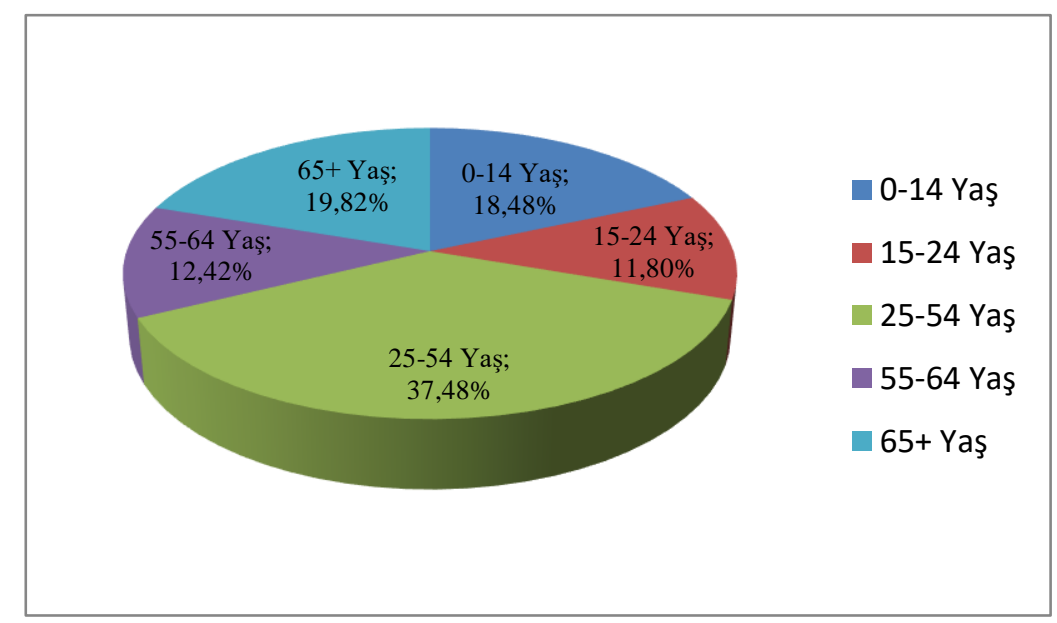

Şekil 1: Fransa Nüfusunun Yaş Dağılımı

Kaynak: ( Indexmundi'den alınan verilerle yazarın kendisi tarafindan oluşturulmuştur).

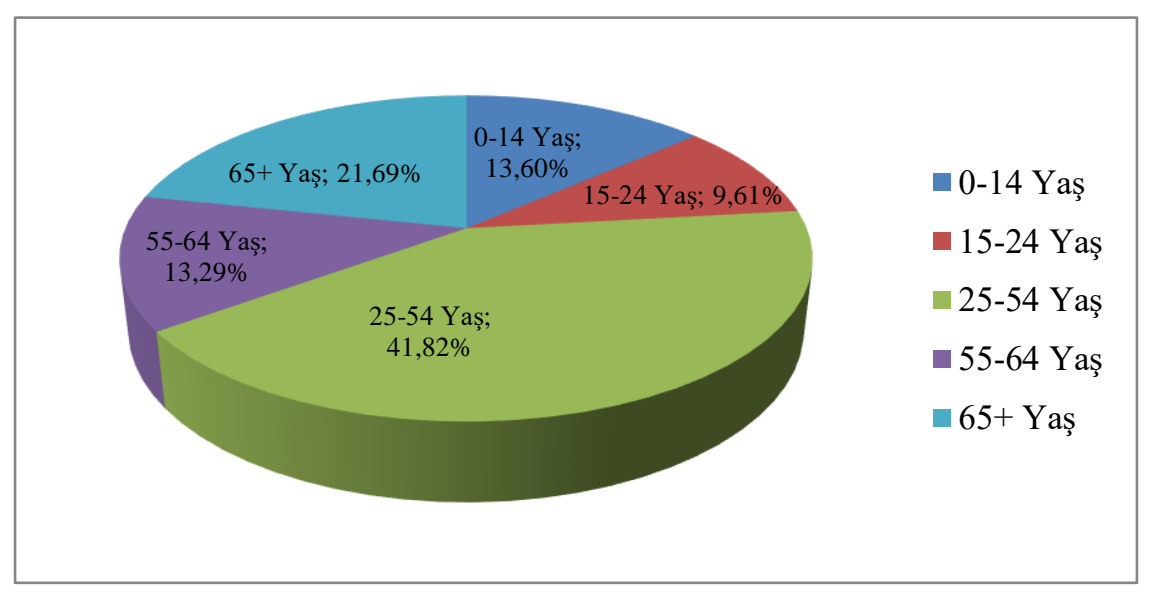

Şekil 2: İtalya Nüfusunun Yaş Dağglımı

Kaynak: ( Indexmundi'den alınan verilerle yazarın kendisi tarafından oluşturulmuştur).

(Wikipedia, 2020a) ancak ilk önlemlerin alınması 15 Mart 2020'ye tarihlenmektedir (BBC, 2020). İtalya'da ise ilk vakalar 31 Ocak 2020 tarihinde görülmüş, (Wikipedia, 2020b) 10 Mart 2020'de ise ilk önlemler alınmaya başlanmıştır (Pinar, 2020). 


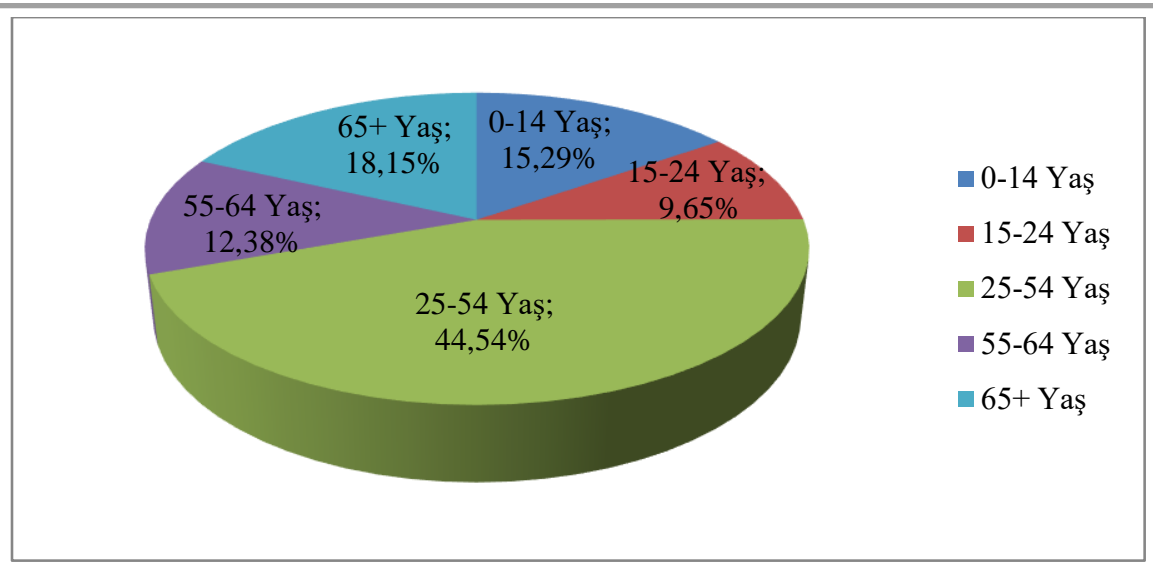

Şekil 3: İspanya Nüfusunun Yaş Dağılımı

Kaynak: ( Indexmundi'den alınan verilerle yazarın kendisi tarafından oluşturulmuştur).

Belirtilen tüm bu hususların sayısal verilerle gün yüzüne çıkarılması ise tüm dünyayla beraber, $A B$ ve Birliğin pek çok alanda başarı sağlamış en önemli üye devletlerini etkileyerek insani güvenlik krizine yol açan pandeminin yarattı̆̆ mevcut durumun daha somut şekilde anlaşılması açısından önem arz etmektedir. İnsani güvenliğe ilişkin kavramsal çerçevenin çizildiği ilgili bölümde ortaya konulduğu üzere insani güvenlik; ekonomik güvenlik, gıda güvenliği, sağlık güvenliği, siyasi güvenlik, çevre güvenliği, kişisel güvenlik ve toplum güvenliği şeklinde yedi alanı kapsamaktadır. Ancak çalışma zarfında insani güvenliğe, AB (Almanya, Fransa, İtalya ve İspanya özelinde) ve Covid-19 bağlamında yaklaşıldığı için insani güvenliğin sadece sağlık ve ekonomi güvenliği unsurları bağlamında bir analiz ortaya konulmaktadır. Çünkü insani güvenliğin diğer unsurları konu bağlamında uygun bir analiz yapılmasına olanak tanımamaktadır. Bir diğer ifadeyle, ekonomik güvenlik ve sağlı güvenliği dışındaki unsurların kavramsal çerçeve bölümünde ortaya konulduğu üzere kendi içlerinde taşıdıkları anlam, bu unsurların Covid-19 bağlamında analiz edilmesine engel olmaktadır.

Bir bütün olarak AB'yi etkileyen insani güvenlik bir “şemsiye” başlık, sağlık güvenliği ve ekonomik güvenlik de alt başlıklar olarak ele alındığında Almanya, Fransa, İtalya ve İspanya'ya ilişkin veriler şu şekildedir:

Tablo 3: Sağlık Verileri- Covid 19'un Bilançosu- 28 Haziran 2020

\begin{tabular}{|l|l|l|l|}
\hline Devletler & Toplam Vaka & İyileşen & Ölüm \\
\hline Almanya & 195.687 & $177 \mathrm{~B}$ & 9.031 \\
\hline Fransa & $163 \mathrm{~B}$ & 75.649 & 29.778 \\
\hline İtalya & $257 \mathrm{~B}$ & $189 \mathrm{~B}$ & 34.724 \\
\hline İspanya & $295 \mathrm{~B}$ & $150 \mathrm{~B}$ & 28.341 \\
\hline
\end{tabular}

Kaynak: (Coronavirus Update'den elde edilen verilerle yazarın kendisi tarafindan oluşturulmuştur).

Tablo 4: Sağlık Verileri- Aktif Vakaların En Yüksek Olduğu Zaman Dilimi

\begin{tabular}{|l|l|l|}
\hline Devletler & Tarih & Aktif Vaka Sayıs \\
\hline Almanya & 6 Nisan 2020 & 72.865 \\
\hline Fransa & 28 Nisan 2020 & 59.313 \\
\hline İtalya & 19 Nisan 2020 & 108.165 \\
\hline İspanya & Veri Yok & Veri Yok \\
\hline
\end{tabular}

Kaynak: (Coronavirus Update'den elde edilen verilerle yazarın kendisi tarafindan oluşturulmuştur). 
Sağlık güvenliğine etki ederek insani güvenlik krizine yol açan salgın nedeniyle büyük oranda insani kayıplar yaşanmaktadır. Tablo 3'den görüldüğü üzere salgın nedeniyle her ne kadar düşük bir ölüm oranına sahip olsa da İspanya, İtalya ve Fransa'dan sonra en fazla vakaya sahip olan devlet Almanya'dır. Almanya'da diğer devletlere kıyasla ölüm oranının az olması altında ise virüsün öncelikle genç nüfusa bulaşmasının, yüksek oranda test yapılmasının ve güçlü sağlık kapasitesinin etkili olduğu ifade edilmektedir (Sarı, 2020). Ancak yüksek oranda test yapılması ve güçlü bir sağlık kapasitesi konusunda çelişkiler bulunmaktadır. Nitekim bazı kaynaklarda haftada 300 bin, bazı kaynaklarda ise günde 100 bin test yapıldığına ilişkin veriler göz önüne alındığında öncelikle bu duruma ilişkin bir tutarsızlık olduğu görülmektedir. Öte yandan, haftada 300 bin test yapıldığı farz edilirse 83 milyonluk nüfusun tamamına test yapılması yaklaşık beş yıl gibi bir süreye tekabül etmekte, günde 100 bin test yapıldığ 1 düşünülürse nüfusun tamamı için yaklaşık iki buçuk yıl gerekmektedir. Bununla beraber, Almanya sürekli vurgu yapılan gelişmiş bir sağlık kapasitesinden ziyade acil durumlarda hızlı önlem alabilme mekanizmasının ve halkın bilinçlilik düzeyinin oldukça gelişmiş olması bağlamında başarı ölçekli bir mücadele sergilemiştir. Nitekim Almanya'nın sağlık kapasitesiyle ilgili sorunlar olduğu görülmektedir. Eurostat'ın 100 bin kişiye düşen hastane yatağı ve doktor sayılarına ${ }^{6}$ ilişkin ortaya koyduğu veriler ve nüfus bağlamında yapılan analiz sonucunda 83 milyonluk nüfusa 664 bin yatak ve 352.750 doktor düştüğü,28 Haziran 2020 tarihinde hâlen hasta olanlar verisiyle (8.163) yapilan analizde aktif korona vakalarının doktor kapasitesinin \% 2'sini kullanabildiği sonucuna ulaşılmıştır ki aktif vaka sayısının en yüksek olduğu 6 Nisan 2020'de (72.865) ise vakalar doktor kapasitesinin \% 20'sini kullanabilmiştir. Öte yandan, Fransa'da 60 milyon kişiye 358.800 yatak ve 202.200 doktor düşmektedir. 28 Haziran 2020'de aktif korona vakaları (57.509) doktor kapasitesinin \%2,8'ini kullanmış ve aktif vaka sayısının en yüksek olduğu 28 Nisan 2020'de (59.313) vakalar, doktor kapasitesinin \% 29'undan yararlanabilmiştir. Diğer taraftan, İtalya'da 60 milyon kişiye 190.800 yatak ve 239.400 doktor düştüğü, 28 Haziran 2020 tarihinde hâlen hasta olanların (16.836) doktor kapasitesinin \% 7'sini, aktif vaka sayısının en yüksek olduğu 19 Nisan tarihinde (108.165) ise vakaların, doktor kapasitesinin \% 45'ini kullanabildiği sonucuna ulaşılmıştır. İspanya'da ise 46 milyon kişiye 136.620 yatak ve 178.480 doktor düştüğü sonucuna ulaşılmakla birlikte, veri girişi yapılmamasından dolayı aktif vakaların doktor kapasitesinin yüzde kaçını kullanabildiğine ilişkin bir sonuca ulaşılamamıştır. Elde edilen veriler ekseninde hastanede bulunan hastaların sadece korona vakası olmadığı düşünüldügünde mevcut durumun Almanya dâhil tüm devletler bağlamında pek de iç açıcı olmadığı görülmektedir.

Tablo 5: Ekonomik Veriler -GSYİH-Büyüme Oranı (\%)

\begin{tabular}{|l|c|c|c|c|}
\hline \multicolumn{1}{|c|}{ Devletler } & $\mathbf{2 0 1 9}$ & 2019 Son Çeyrek & 2020 İk Çeyrek & $\begin{array}{c}\text { 2020 Sonu } \\
\text { Tahmin }\end{array}$ \\
\hline Almanya & 0,6 & $-0,1$ & -7 & $-7,8$ \\
\hline Fransa & 1,5 & $-0,1$ & $-7,2$ & $-12,5$ \\
\hline İtalya & 0,3 & $-0,2$ & $-9,1$ & $-12,8$ \\
\hline İspanya & 2 & 0,4 & -8 & $-12,8$ \\
\hline
\end{tabular}

Kaynak: (OECD ve World Economic Outlook 2020, IMF'den alınan veriler ekseninde yazarın kendisi tarafından oluşturulmuştur).

\footnotetext{
${ }^{6}$ Almanya'da 100 bin kişiye düşen hastane yatağı 800 ve doktor sayıs 425 'tir. Fransa'da 100 bin kişiye düşen hastane yatağı 598 ve doktor sayısı 337'dir. İtalya'da 100 bin kişiye düşen hastane yatağı 318 ve doktor sayısı 399 iken İspanya'da 100 bin kişiye 297 yatak ve 388 doktor düşmektedir. ( Eurostat, 2020a; Eurostat, 2020b).
} 
Tablo 6: Ekonomik Veriler -Kişi Başına GSYİH (\$)

\begin{tabular}{|l|c|c|c|c|c|}
\hline \multicolumn{1}{|c|}{ Devletler } & 2019 1. Çeyrek & 2019 2. Çeyrek & 2019 3. Çeyrek & 2019 4. Çeyrek & 2020 1. Çeyrek \\
\hline Almanya & 55.608 & 55.997 & 56.489 & 56.629 & 55.565 \\
\hline Fransa & 48.223 & 40.043 & 49.600 & 49.819 & 47.265 \\
\hline İtalya & 43.566 & 44.082 & 44.400 & 44.484 & 42.341 \\
\hline İspanya & 41.526 & 42.077 & 42.446 & 42.727 & 40.597 \\
\hline
\end{tabular}

Kaynak: (OECD'den alınan veriler ekseninde yazarın kendisi tarafından oluşturulmuştur).

Tablo 7:Ekonomik Veriler -Enflasyon Oranı (\%)

\begin{tabular}{|c|c|c|}
\hline Devletler & 2019 Son Çeyrek & 2020 1. Çeyrek \\
\hline Almanya & 1,24 & 1,64 \\
\hline Fransa & 1,09 & 1,3 \\
\hline İtalya & 0,29 & 0,7 \\
\hline İspanya & 0,44 & 1,4 \\
\hline
\end{tabular}

Kaynak: (OECD'den elde edilen verilerle yazarın kendisi tarafından oluşturulmuştur).

Tablo 8: Ekonomik Veriler- İhracat ve İthalat (Milyon \$)

\begin{tabular}{|c|c|c|c|c|c|c|}
\hline Devletler & $\begin{array}{c}\text { 2019 Aralık } \\
\text { İhracat }\end{array}$ & $\begin{array}{c}\text { 2020 Ocak } \\
\text { İhracat }\end{array}$ & $\begin{array}{c}\text { 2020 Subat } \\
\text { İhracat }\end{array}$ & $\begin{array}{c}\text { 2019 Arallk } \\
\text { İthalat }\end{array}$ & $\begin{array}{c}\text { 2020 Ocak } \\
\text { İthalat }\end{array}$ & $\begin{array}{c}\text { 2020 Şubat } \\
\text { İthalat }\end{array}$ \\
\hline Almanya & 122.284 & 121.036 & 121.090 & 101.518 & 101.016 & 98.555 \\
\hline Fransa & 51.814 & 50.230 & 49.867 & 47 & 46 & 45 \\
\hline İtalya & 44.404 & 44.951 & 44.489 & 58 & 56 & 52 \\
\hline İspanya & 27.880 & 26.671 & 26.883 & 30.143 & 28.847 & 29.173 \\
\hline
\end{tabular}

Kaynak: (Knoema'dan elde edilen verilerle yazarın kendisi tarafından oluşturulmuştur).

Tablo 9: Ekonomik Veriler- İşsizlik Oranı (\%)

\begin{tabular}{|c|c|c|c|}
\hline Devletler & $\mathbf{2 0 1 9}$ & 2019 Son Çeyrek & 2020 1. Çeyrek \\
\hline Almanya & 3,2 & 3,23 & 3,9 \\
\hline Fransa & 8,5 & 8,23 & 10,4 \\
\hline İtalya & 10 & 9,5 & 12,7 \\
\hline İspanya & 14,1 & 13,83 & 20,8 \\
\hline
\end{tabular}

Kaynak: (OECD ve IMF'den elde edilen verilerle yazarın kendisi tarafindan oluşturulmuştur).

Covid-19 pandemisinin Almanya, Fransa, İtalya ve İspanya bağlamında insani güvenliğin unsurlarından biri olan ekonomik güvenliğe olan etkisinin analizi çerçevesinde tablo 5-9 aras1 ortaya konan verilerden, söz konusu salgının ilgili devletlerin ekonomik güvenliğini tehdit ettiği ve dolayısıyla insani güvenliğin önünde ciddi bir tehdit oluşturduğu sonucuna ulaşılmaktadır. Salgın nedeniyle devletlerin ekonomilerinin küçülmesi, ekonomik aktivitelerin yavaşlaması, fiyatların genel düzeyinin artması doğrudan bireylere etki eden önemli bir hususu teşkil etmektedir. Bu bağlamda, tablolarda görüldüğü gibi ve özellikle 2019 yılının son çeyreği ve 2020'nin ilk çeyreğine ilişkin veriler ekseninde büyüme oranının, kişi başına düşen GSYIH, ihracat, ithalat oranlarının düştüğü, öte yandan işsizliğin yükseldiği ve son dönemde devletlerin önlemleri gevşetmesiyle beraber enflasyon oranının yükseldiği görülmektedir. Doğrudan insani güvenliğe etki eden ekonomik güvenlik dengesinin bozulması altında pandemi nedeniyle pazar ve taleplere yönelik daralmalar, sınırlarda alınan önlemler, üretime ara verilmesi, işyerlerinin kapatılması, sokağa çıkma ve seyahat yasakları gibi faktörler bulunmaktadır.

Sonuç olarak, salgın AB düzleminde ve özel olarak üye devletler bağlamında insani güvenlik krizine yol açmıştır. Covid-19 bağlamında insani güvenliğin iki unsuru olan sağlık güvenliği ve ekonomik güvenliğe ilişkin analiz edilen verilerle son sekiz aydır dünya genelinde ve 
Birlik özelinde mücadele edilen salgının, insani güvenliğe çok ciddi bir tehdit olduğu görülmektedir. Buna rağmen, hem ortak bir sağlık politikası olmaması, bu alanın devletlerin münhasır yetkilerinde kalması hem de sağlıkla ilişkili ürünlerin üretimindeki dışa bağımlılık ve dayanışma ve iş birliğinin tesis edilmesindeki sorunlar nedeniyle $A B$ için salgınla mücadele, sarsıntılı bir deprem etkisi yaratırken bu husus Birliğin en güçlü, etkili ve önemli üye devletleri açısından da söz konusu olmuştur. Fransa, İtalya ve İspanya ile kıyaslandığında çok daha başarılı bir mücadele sergileyen Birliğin en önemli üyelerinden Almanya da bile sorunların olduğu görülmektedir ki bu husus diğer üç üye devlet ekseninde oldukça derin bir etkiye neden olmuştur. Bir diğer ifadeyle, salgınla mücadelede üye devletler kendi içlerine dönerek ulusal mücadele refleksi geliştirse de küresel tehditlerle mücadele, bütüncül ve ortak politika gerektirdiğinden üye devletlerin ve dolayısıyla Birlik vatandaşlarının da büyük ölçüde zarar gördüğüne şahit olunmaktadır.

\section{Sonuç}

2019 yılı Aralık ayında Çin'in Wuhan kentinde ortaya çıkan ve büyük bir hızla tüm dünyaya yayılan Koronavirüs (Covid-19) salgını, büyük resme bakıldığında küresel bir krize yol açmıştır. Dünya çapında olumsuz sonuçlarının tecrübe edildiği bu kriz, insani güvenliğe yönelik ciddi bir tehdit oluşturmuştur. Artık güvenliğe salt devlet odaklı yaklaşan geleneksel güvenlik yaklaşımları perspektifinden bakılamayacak kadar karmaşık, tehditlerin boyut değiştirdiği ve bu noktada bireyin önceliklendirilmesinin gerektiği bir süreç içindeyken bu durum yaşanan Covid-19 salgını ile beraber bir kez daha gün yüzüne çıkmıştır. Bir diğer ifadeyle temel hakların, ihtiyaçların, yaşam koşullarının, refahın sağlanması ve insanoğluna yönelmiş tüm tehditlerden bireylerin korunması bağlamında güvenlik gündeminin insani değerler üzerine temellendiği ve bireyin önceliği merkezli insani güvenlik yaklaşımı, tüm bu unsurların çok daha ötesinde son sekiz aydır üzerinde tartışılan en önemli husus olan Covid-19 salgınıyla çevrelenmiştir.

Tüm dünyayı derinden etkileyen Covid-19 salgını bağlamında yaşanan kriz, Avrupa Birliği çerçevesinde sarsıcı bir deprem etkisi yaratmıştır. Tüm dünya devletleriyle beraber topyekûn $A B$ üye devletlerini beklemeyen bir anda yakalayan salgın, Birliğin uzun dönemdir yaşadığı, ekonomik krizin, popülizmin yükselmesinin, mülteci karşıtlarının, yükselen milliyetçiliğin, yabancı düşmanlığının ve Brexit'in neden olduğu sorunlarla mücadelesine ek bir sorun getirmiştir. Söz konusu salgınla mücadele bağlamında AB'nin geleceğine ilişkin tartışmaların devam etmesi bir yana, somut olan realite hem $\mathrm{AB}$ ve tüm üye devletler düzleminde hem de $\mathrm{AB}$ 'nin en güçlü devletleri olan Almanya, Fransa, İtalya ve İspanya özelinde ciddi bir insani güvenlik sorunu yaşanmasıdır.

İnsani güvenlik bağlamında Covid-19 salgını sürecini, AB'ye ve Birliğin en önemli üye devletleri Almanya, Fransa, İtalya ve İspanya'ya yansıtan bu çalışma zarfında salgınla beraber insani güvenliğin iki unsuru olan sağlık güvenliği ve ekonomik güvenliğin ciddi oranda darbe aldığ 1 ve bu bağlamda insani güvenliğin sağlanması konusunda hem Birliğin hem de söz konusu devletlerin yeteri oranda başarı sağlayamadığ sonucuna ulaşılmıştır. Salgınla mücadelede diğer üye devletlere kıyasla daha yüksek başarı sağlayan Almanya'nın bile sorunlara gebe kaldığı görülmekle beraber Fransa, İtalya ve İspanya'daki durum ise oldukça menfidir. Öyle ki salgın, dünya'da sağlık hizmetleri konusundaki hassasiyetin her geçen gün arttığına ilişkin söylemlerin teoride kaldığını gözler önüne sermiştir. Ayrıca tarihsel kökeni 2003 yılındaki "Avrupa Güvenlik Strateji" belgesine dayanan, 2004 yılında yayımlanan "Barselona Raporu", 2007 y1lında yayımlanan "Madrid Raporu" ve 2016 yılında yayımlanan " Avrupa Küresel Strateji” belgesi ile taçlandırılan AB'nin insani güvenlik söyleminin bu salgınla beraber teoride kaldığı tecrübe edilmiştir.

Sonuç olarak, dünyayı derinden sarsan bu tehdit bağlamında küresel sistemde yer alan tüm devletlerle beraber, $\mathrm{AB}$ özelinde üzerinde durulması gereken konulardan biri can kayıplarının mümkün olan en az düzeyde tutularak, krizin en az hasarla atlatılması iken diğeri ise benzer 
krizlerin önüne geçilebilecek adımların atılmasıdır. Nitekim koronavirüs salgını gelinen bu son süreçte ciddi oranda can ve ekonomik kayıpların yaşandığı bir dünya kompozisyonuna neden olmuştur. Bu noktada devletlerin insani güvenliğe yönelik bu yönde bir tehdide karşı mücadelede tıpkı Almanya'da olduğu gibi yeterli maddi kaynakları ayırması, sağlı hizmetlerinin geliştirilmesi bilincine erişmeleri önem arz etmektedir. Buna rağmen, ulusal düzlemde alınan tedbirler tüm dünya devletlerini etkileyen bu sorunun bertaraf edilmesinde yetersiz kalmakta ve bu noktada uluslararası iş birliği ve dayanışmanın öneminin belirginleşmesine neden olmaktadır. Öyle ki salgın hastal1klar, küresel bir meydan okuma ve kolektif bir mücadele gerektirmektedir. Nitekim AB bağlamında da tecrübe edilen bu husus, tüm dünya genelinde ve Birlik özelinde küresel ve bölgesel iş birliğinin iç içe geçtiği, daha kapsamlı, bütüncül, ortak irade ve dayanışma üzerine temellenen bir insani güvenlik yaklaşımına duyulan ihtiyacı gözler önüne sermektedir.

\section{Kaynakça}

Aksu, M. ve Turhan, F. (2012). “ Yeni Tehditler, Güvenliğin Genişleme Boyutları ve İnsani Güvenlik”.Uluslararası Alanya Işsletme Fakültesi Dergisi, 4(2): 69-80.

Albrecht, U., Chinkin, C., Dervis, K., Dwan, R., Giddens, A., Gnesotto, N. ve Serre, N. (2004). “A Human Security Doctrine for Europe: The Barcelona Report of the Study Group on Europe's Security Capabilities". http://eprints.lse.ac.uk/40209/, (Erişim Tarihi: 13.04.2020).

Albrecht, U., Chinkin, C., Celador, G. C., Flechtner, S., Glasius, M., Kaldor, M. ve Weisskirchen, G. (2007). "A European Way of Security: The Madrid Report of the Human Security Study Group Comprising a Proposal and Background Report". http://www.worldgovernance.org/IMG/pdf_0078_A_European_Way_of_Security.pdf, (13.04.2020).

Ataman, M.(2020). "Coronavirus: A Human Security Issue".https://www.setav.org/en/coronavirusa-human-security-issue/, (Erişim Tarihi: 06.03.2020).

Bağbaşlığlu, A. (2020). "Koronavirüs Salgınının Uluslararası Örgütlerin Meşruiyeti ve Etkinliğine Yönelik Yansımaları: NATO Örneği”. Turkish Studies, 15(4): 95-108.

Bajpai, K. (2000). "Human Security: Concept and Measurement". http://www.hegoa.ehu.es/dossierra/seguridad/Human_security_concept_and_measurem ent.pdf, (Erişim Tarihi: 12.04.2020).

Başay, E. (2020). “AB Komisyonu Başkanı: Avrupa İçin Bir Marshall Planı'na İhtiyaç Var”. https://www.aa.com.tr/tr/dunya/ab-komisyonu-baskani-avrupa-icin-bir-marshall-planinaihtiyac-var/1793107, (Erişim Tarihi: 17.06.2020).

BBC. (2020). "Koronavirüs: İspanya, Hollanda ve Fransa'da Geniş Kapsamlı Kısıtlamalar". https://www.bbc.com/turkce/haberler-dunya-51896477, (Erişim Tarihi: 17.06.2020).

Bedeski, R. (2000). " Human Security, Knowledge and the Evolution of the Northeast Asian State". http://www.globalcentres.org/docs/bedeski.html, (Erişim Tarihi: 02.03.2020).

Breslin, S. ve Christou, G. (2015). " Has the Human Security Agenda Come of Age? Definitions, Discourses and Debates”, Contemporary Politics, 21(1): 1-10.

Borrel, J. (2020). “The Post Coronavirüs World Is Already Here”. https://www.ecfr.eu/page//the_post_coronavirus_world_is_already_here.pdf, (Erişim Tarihi: 25.06.2020).

Cebeci, A. (2020). "Kapitalist Toplumsal İlişkilerde Dönüşüm: Dönüşümün Katalizörü Olarak Salgın”. Turkish Studies, 15(4): 1409-1428. 
European Commission. (2020a). “Timeline of EU Action”. https://ec.europa.eu/info/live-worktravel-eu/health/coronavirus-response/timeline-eu-action_en, (Erişim Tarihi: 06.09.2020).

European Commission. (2020b). "European Commission's Coronavirus Response Team". https://ec.europa.eu/info/live-work-travel-eu/health/coronavirus-response/europeancommissions-action-coronavirus_en, (Erişim Tarihi: 05.09.2020).

ECDC. (2020). "About Us”. https://www.ecdc.europa.eu/en/about-ecdc, (Erişim Tarihi: 06.09.2020).

Euronews. (2020). “Fransa'da Bir Ayını Dolduracak Karantina Uygulaması Yeniden Uzatılacak”. https://tr.euronews.com/2020/04/08/fransa-da-bir-ayini-dolduracak-karantina-uygulamasiyeniden-uzatilacak, (Erişim Tarihi: 17.06.2020).

$\begin{array}{lllll}\text { Eurostat. } & \text { (2020a). } & \text { "Hospital } & \text { Beds } & 000\end{array}$ Inhabitants".https://ec.europa.eu/eurostat/tgm/table.do?tab=table\&init=1\&language=en\&pc ode $=$ tps00046\&plugin $=1$, (Erişim Tarihi: 30.04 .2020$)$.

Eurostat. (2020b). "Practising Physicians Per 100.000 Inhibitants". https://ec.europa.eu/eurostat/tgm/table.do?tab=table\&init=1\&language $=$ en $\&$ pcode $=t p s 000$ 44\&plugin=1, (Erişim Tarihi: 30.04 .2020 ).

European Security Strategy. (2003).http://data.consilium.europa.eu/doc/document/ST-15895-2003INIT/en/pdf, (Erişim Tarihi: 23.04. 2020).

European

Security

Strategy. (2009).https://www.consilium.europa.eu/media/30823/qc7809568enc.pdf, (Erişim Tarihi: 01.04.2020).

European Global Security Strategy. (2016). “A Global Strategy for the European Union's Foreign and Security Policy".http://eeas.europa.eu/archives/docs/top_stories/pdf/eugs_review_web.pdf, (Erişim Tarihi: 23.04.2020).

Glasius M. ve Kaldor, M. (2005).“Individuals First: A Human Security Strategy for the EU".IPG,62-82.

GTRC. (t.y). "Comparison of Human Security Definitions". http://www.gdrc.org/sustdev/husec/Comparisons.pdf, (Erişim Tarihi: 05.06.2020).

Indexmundi. (2019a). "France Demographics Profile 2019". https://www.indexmundi.com/france/demographics_profile.html, (Erişim Tarihi: 27.05.2020).

Indexmundi. (2019b). "Italy Profile 2019”.https://www.indexmundi.com/italy/demographics_profile.html, (Erişim Tarihi: 27.05.2020).

Indexmundi. (2019c). "Spain Profile 2019”.https://www.indexmundi.com/spain/demographics_profile.html, (Erişim Tarihi: 27.05.2020).

Kotsopoulos, J. (2006). "A Human Security Agenda for the EU?". https://www.files.ethz.ch/isn/25154/245249_Human\%20Security\%20IP.pdf, (Erişim Tarihi: 16.04.2020).

Liotta, P. H. ve Owen, T. (2006a). "Why Human Security”. The Whitehead Journal of Diplomacy and International Relations, 37-52. 
Liotta, P. H. ve Owen, T. (2006b). "Symbolic Security: The EU Takes on Human Security Parameters". The Journal of the US Army War College, 36(3): 85-102.

Ntv. (2020). “Fransa'da İlk Koronavirüs Vakası 27 Aralık'ta Görüldü”.https://www.ntv.com.tr/dunya/fransada-ilk-corona-virus-vakasi-27-araliktagoruldu,E_FXUwFRfkyImSXrP5zFXA, (Erişim Tarihi: 12.06.2020).

Mcquinnes, R. (2020). “EU on Brink: Coronavirus a 'Mortal Danger' y Brussels Bloc-Dire Warning". $\quad$ https://www.express.co.uk/news/world/1262301/eu-news-coronaviruseuropean-union-france-outbreak, (Erişim Tarihi: 22.06.2020).

Nef, J. (1999). Human Security and Mutual Vulnerability. International Development Research Centre.

Ovalı, Ş. (2006). "Ütopya ile Pratik Arasında: Uluslararası İlişkilerde İnsan Güvenliği Kavramsallaştırması”.Uluslararası İlişkiler, 3(10): 3-50.

Paris, R. (2001). “ Human Security: Paradigm Shift or Hot Air?”. International Security, 26(2): 87102.

Pınar, Ö. (2020). “İtalya'da Koronavirüs Karantinası: Dört Hafta İçinde Neler Yaşandı, Hangi Önlemler Alındı?". https://www.bbc.com/turkce/haberler-dunya-52186410, (Erișim Tarihi: 17.06.2020).

Sar1, A. (2020). “ Almanya'nın Kovid-19 Karnesi”. https://www.aa.com.tr/tr/analiz/almanyaninkovid-19-karnesi/1819866, (Erişim Tarihi: 20.06.2020).

Schuman Declaration. (1950). https://europa.eu/european-union/about-eu/symbols/europeday/schuman-declaration_en, (Erişim Tarihi: 28.06.2020).

Sira, H. ve Grans, J. (2010). "The Promotion of Human Security in EU Security Policies". http://aei.pitt.edu/14987/1/INEX_PB7_by_Sira_\%26_Grans_e-version.pdf, (Erişim Tarihi: 20.04. 2020).

Tangör, B. (2012). "Kuramsal Tartışmalar Işı̆̆ında İnsan Güvenliği ve Politikaları”. Uluslararası Hukuk ve Politika, 8(30): 59-92.

Thomas, C. (1999). “Intoduction”. Caroline Thomas ve Peter Wilkin (Edt.), Globalization, Human Security and the African Experience, (1-20), Lynne Rienner Publishers.

TÜBA. (2020). "Covid-19 Pandemi Değerlendirme Raporu".http://www.tuba.gov.tr/tr/yayinlar/suresiz-yayinlar/raporlar/covid-19-pandemidegerlendirme-raporu, (Erişim Tarihi: 01.05.2020).

UN Human Development Report. (1994). http://hdr.undp.org/sites/default/files/reports/255/hdr_1994_en_complete_nostats.pdf, (Erişim Tarihi: 22.05.2020).

Wikipedia. (2020a). "İspanya'da Covid-19 Pandemisi". https://tr.wikipedia.org/wiki/\%C4\%B0spanya\%27da_COVID-19_pandemisi, (Erişim Tarihi: 17.06.2020).

Wikipedia. (2020b). "İtalya'da Covid-19 Pandemisi". https://tr.wikipedia.org/wiki/\%C4\%B0talya\%27da_COVID-19_pandemisi, (Erişim Tarihi: 17.06.2020).

World Economic Outlook. (2020). https://www.imf.org/en/Publications/WEO/Issues/2020/06/24/WEOUpdateJune2020 (Erişim Tarihi: 14.05.2020). 
Yenal, S. (2020). "COVID-19 Salgınının Uluslararası Güvenlik Açısından Değerlendirilmesi”. Turkish Studies, 15(4): 1315-1329.

Yılmaz, S. (2017). Uluslararası Güvenlik: Teori, Pratik ve Gelecek. Kaynak Yayınları.

https://data.oecd.org/price/inflation-cpi.htm

https://www.imf.org/external/datamapper/NGDP_RPCH@WEO/DEU?zoom=DEU\&highlight=DE $\mathrm{U}$

https://www.imf.org/external/datamapper/NGDP_RPCH@WEO/ESP

https://www.imf.org/external/datamapper/NGDP_RPCH@WEO/ITA

https://www.imf.org/external/datamapper/NGDP_RPCH@WEO/FRA

https://knoema.com/search?query=Import+2020\&pageIndex=\&scope $=\&$ term $=\&$ correct $=\&$ source $=$ Header

$\mathrm{https}: / /$ knoema.com/search?query=export $\% 202020$

https://stats.oecd.org/index.aspx?queryid=66948

https://www.worldometers.info/coronavirus/ 